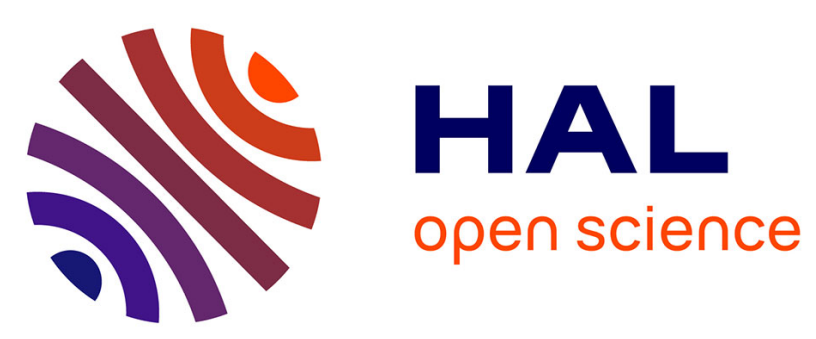

\title{
Investigation of tool geometry effect and penetration strategies on cutting forces during thread milling
}

Vishal S. Sharma, Guillaume Fromentin, Gérard Poulachon, Romain Brendlen

\section{To cite this version:}

Vishal S. Sharma, Guillaume Fromentin, Gérard Poulachon, Romain Brendlen. Investigation of tool geometry effect and penetration strategies on cutting forces during thread milling. International Journal of Advanced Manufacturing Technology, 2014, 74 (2014), pp.913. hal-01066294

\section{HAL Id: hal-01066294 \\ https://hal.science/hal-01066294}

Submitted on 6 May 2015

HAL is a multi-disciplinary open access archive for the deposit and dissemination of scientific research documents, whether they are published or not. The documents may come from teaching and research institutions in France or abroad, or from public or private research centers.
L'archive ouverte pluridisciplinaire HAL, est destinée au dépôt et à la diffusion de documents scientifiques de niveau recherche, publiés ou non, émanant des établissements d'enseignement et de recherche français ou étrangers, des laboratoires publics ou privés. 


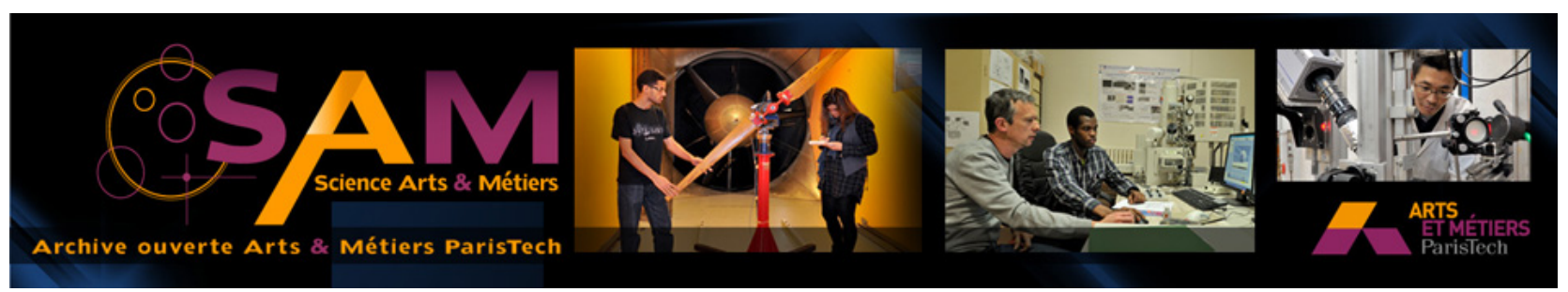

Science Arts \& Métiers (SAM)

is an open access repository that collects the work of Arts et Métiers ParisTech researchers and makes it freely available over the web where possible.

This is an author-deposited version published in: http://sam.ensam.eu

Handle ID: .http://hdl.handle.net/10985/8565

\section{To cite this version :}

Vishal SHARMA, Guillaume FROMENTIN, Gérard POULACHON, Romain BRENDLEN Investigation of tool geometry effect and penetration strategies on cutting forces during thread milling - International Journal of Advanced Manufacturing Technology - Vol. 74, n²014, p.913 2014 


\title{
Investigation of tool geometry effect and penetration strategies on cutting forces during thread milling
}

\author{
Vishal S. Sharma • Guillaume Fromentin • \\ Gérard Poulachon • Romain Brendlen
}

\begin{abstract}
The application of thread milling is increasing in industry because of its inherent advantages over other thread cutting techniques. The objective of this study is to investigate the effect of milling cutter tool geometry on cutting forces during thread milling. The proposed method can compare the performance of milling cutters in spite of the different number of tooth. The best thread milling cutter among the studied tools was determined from the cutting forces point of view. Furthermore, this study also pinpoints the best penetration strategy that provides minimum cutting forces. Lower cutting force variations will lead to fewer vibrations of the tool which in turn will produce accurate part.
\end{abstract}

Keywords Thread milling · Cutting forces $\cdot$ Cutting tool geometry $\cdot$ Penetration strategies

$\begin{array}{ll}\text { Nomenclature } \\ \mathrm{a}_{\mathrm{doc}} & \text { Axial depth of cut }(\mathrm{mm}) \\ \mathrm{D} & \text { Thread nominal diameter }(\mathrm{mm}) \\ \mathrm{D}_{\mathrm{m}} & \text { Maximum mill diameter }(\mathrm{mm}) \\ \mathrm{EP} & \text { External point of the mill } \\ \mathrm{fce} & \text { Front cutting edge } \\ \mathrm{FM} & \text { Full machining } \\ \mathrm{f}_{\mathrm{t}} & \text { Feed per tooth }(\mathrm{mm} / \text { tooth/revolution }) \\ \mathrm{f}_{\mathrm{tEP}} & \text { Feed per tooth at external point } \\ & \text { (mm/tooth/revolution) } \\ \mathrm{F}_{\mathrm{x}} & \text { Cutting force X-axis component }(\mathrm{N}) \\ \mathrm{F}_{\mathrm{y}} & \text { Cutting force Y-axis component }(\mathrm{N})\end{array}$

V. S. Sharma $(\square) \cdot G$. Fromentin $\cdot$ G. Poulachon $\cdot$ R. Brendlen Arts et Metiers Paris Tech, LaBoMaP, 71250 Cluny, France e-mail: sharmavs@nitj.ac.in

V. S. Sharma

Department of Industrial \& Production Engineering,

National Institute of Technology, Jalandhar 144011, India
$\mathrm{F}_{\mathrm{z}} \quad$ Cutting force Z-axis component $(\mathrm{N})$

HRP Modified half revolution penetration

HRR Modified half revolution retraction

lce Lower cutting edge

$\mathrm{m}_{\mathrm{d}} \quad$ Milled distance $(\mathrm{mm})$

$\mathrm{n}_{\mathrm{fm}} \quad$ Number of flutes

$\mathrm{N}_{\mathrm{wt}} \quad$ Number of working teeth

P Thread pitch (mm)

PS Penetration strategy

QRP Modified quarter revolution penetration

$\mathrm{r}_{\mathrm{doc}} \quad$ Radial depth of cut (mm)

RF Resultant force (N)

$\mathrm{RF}_{\mathrm{ptp}} \quad$ Peak to peak variations of resultant cutting force $(\mathrm{N})$

$\mathrm{RF}_{\text {rms }}$ Root mean square of resultant cutting force $(\mathrm{N})$

$\mathrm{R}_{\mathrm{mc}} \quad$ Helix radius of mill center trajectory for full machining (mm)

$\mathrm{R}_{\mathrm{mcp}} \quad$ Helix radius of mill center trajectory for penetration (mm)

$r_{p} \quad$ Radial penetration (mm)

SP Straight penetration

uce Upper cutting edge

$\theta_{\text {abtt }} \quad$ Angle between two teeth ( $\left.{ }^{\circ}\right)$

$\theta_{\text {fwa }} \quad$ Flute working angle $\left({ }^{\circ}\right)$

$\theta_{\text {twa }} \quad$ Tooth working angle $\left({ }^{\circ}\right)$

$\gamma_{\mathrm{n}} \quad$ Normal rake angle $\left({ }^{\circ}\right)$

$\gamma_{\text {om }} \quad$ Orthogonal rake angle of the mill $\left(^{\circ}\right)$

$\lambda_{\text {sm }} \quad$ Mill flute angle $\left(^{\circ}\right)$

\section{Introduction}

Thread milling is finding fast adaptation in industry because of its many advantages as enlisted in this section. Only one tool is needed for right and left hand threads and the same tool covers a wide hole diameter range so this allows lower 
inventory and greater cost efficiency. Since the cutting parameters can be adapted and various cutter designs are available, the process can be used to machine difficult-to-machine materials such as titanium alloys, tool steels, stainless steels, hardened steels, and other super alloys. Moreover, the process can be implemented with minimum quantity lubrication (MQL). In the event of tool breakage, it can be easily removed without damaging the component. The thread milling process needs less torque as compared to tapping, for large thread diameters. Furthermore, the use of thread milling also reduces the uncompleted thread length. The limitation associated with the process is its slowness (compared with tapping) and requirement of three-axis computer numerical control (CNC) machine for execution [1, 2]. The complex tool geometry, different milling trajectory coupled with different machining parameters, make thread milling a challenging task. Now, the objective in the current investigation is to find which milling strategy and milling cutter produces minimum cutting forces. This shall reduce vibrations while producing threads and subsequently produce accurate parts. In order to achieve the goal, cutting forces $\left(F_{x}, F_{y}\right.$, and $\left.F_{z}\right)$ were recorded by changing thread nominal diameters, mill flute angles, and penetration strategies. This study makes use of modified half revolution penetration (HRP) strategy and modified quarter revolution (QRP) penetration strategies. These modified strategies offer fewer geometrical errors as compared to unmodified strategies which have been successfully demonstrated [3].

\section{Brief background}

\subsection{Thread milling}

Thread milling operation makes use of milling cutter and a three-axis $\mathrm{CNC}$ machine. The six steps involved in the process are shown in Fig. 1. The first step starts with the thread milling cutter getting in line with the hole axis; this step is called as "infeed." In the second step, the milling cutter moves into the hole up to the programmed depth; this step is named as "axial setting to thread depth." In the third step, milling cutter radially enters into the part and this step is termed as "penetration." There is also Z-axis movement of the milling cutter equal to quarter of the thread pitch (for half revolution penetration). The fourth step is termed as "full machining" in which the thread milling is performed by the milling cutter in a $360^{\circ}$ helical movement. The tool also travels in Z-axis equal to thread pitch in this step. After performing the thread milling operation, the milling cutter moves away from the part using the same strategy as was used during penetration; this step is named as "retraction." Z-axis movement for this step is also same as in the case of penetration step. In the sixth step, the milling cutter is taken out of part and is termed as "thread completed."
The penetration strategies (PS), used in the study, are straight penetration (SP), half revolution penetration (HRP), and quarter revolution penetration (QRP). In SP, the mill engages with the part following a straight line trajectory; there is no Z-axis displacement during this movement. For HRP, the tool follows a half helical path to engage with the part; during this movement, it also travels equal to $\mathrm{P} / 4$ in Z-axis. QRP utilizes quarter helical trajectory for engagement with the part and $\left[\frac{P}{2 \pi} \cdot \arctan \frac{R_{m c p}}{P}\right]$ movement in Z-axis. HRP and QRP strategies are employed in industry; the SP strategy is considered for comparisons with them.

\subsection{Interferences}

It was reported that the process of thread milling leads to interferences and thus, overcutting on the thread flanks [4]. There are two sources for induction of interference in the process, i.e., interferences caused by the penetration step and then by full machining. Interferences caused by full machining are reduced by correcting the radius of the mill center trajectory. A method of reducing interferences during penetration was further proposed and demonstrated, i.e., adopting the modified penetration strategies [3].

\subsection{Cutting forces}

The cutting forces, acting on the tool, are an important aspect of machining. For those concerned with the manufacture of machine tools, knowledge of the cutting forces is needed for performing milling operation, for estimation of power requirements, and for the design of machine tool elements, tool holders and fixtures, adequately rigid and free from vibration.

Cutting force levels, cutting force variations, and vibrations are also linked to mill flute angle. Furthermore, there has to be an optimal value for flute angle [5].

The influences of dynamic radii, cutting feed rate, and radial and axial depths of cut on milling cutting forces has been presented in past [6]. Also systematic studies of the cutting force modeling methods in peripheral milling process in the presence of cutter runout have been successfully reported. Both the above studies are on peripheral milling [7]. The studies on thread milling have indicated that high tool pressure is generated which can result into an excessive tool deflection and tool breakage when milled at full thread depth $[8,9]$. A model proposed cutting forces during the thread milling operations taking into account both surface and edge force components while the cutting edge was modeled from the geometry of the milling cutter. The cutting forces were measured using a dynamometer and compared to the calculated result using the exact uncut chip thickness. The measured cutting forces for the brass workpiece material for a linear path showed good agreement with the simulated cutting forces 


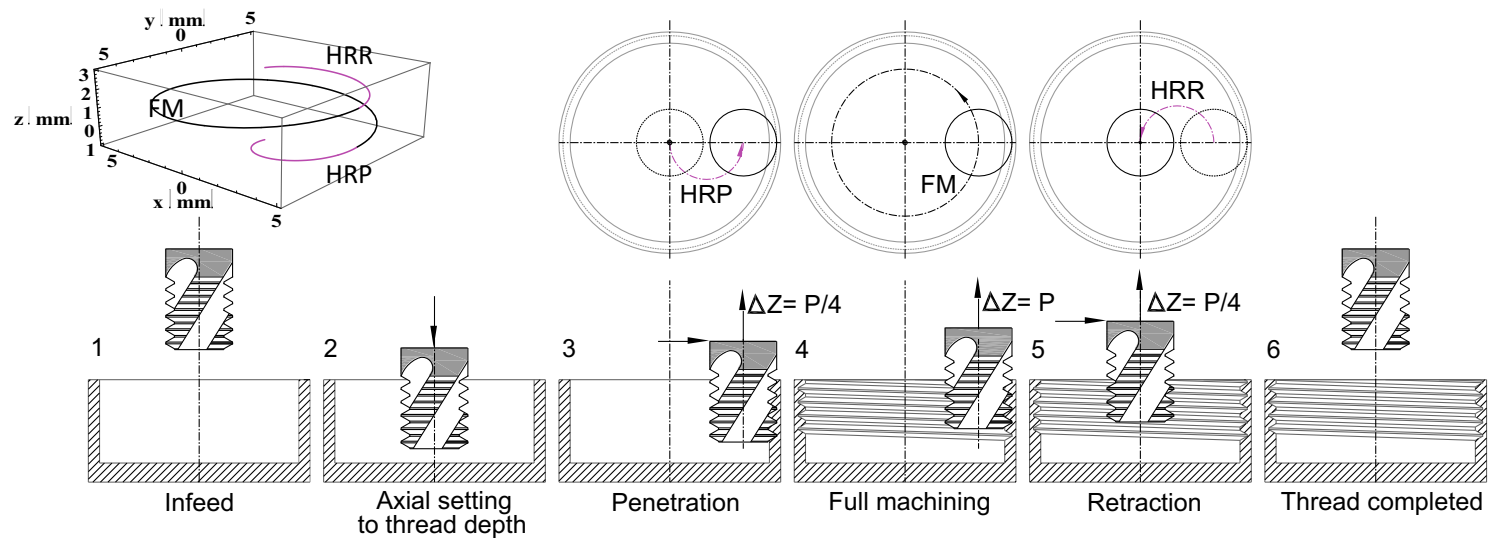

Fig. 1 Steps in thread milling cycle for HRP (right hand thread, down milling)

[10]. Analytical and experimental investigations on the thread milling forces in titanium alloy have been reported. The study helps in complete understanding of geometrical and mechanical aspects in thread milling [11]. From the literature survey, it was observed that most of the work is on milling operations but there is less work reported on thread milling. The current study dwells upon this not reported/unexplored issue.

\subsection{Defining important terms}

Figure 2a, b presents the milling cutter and developed milling cutter, respectively, which are used to define the number of working teeth. The important terms used in the article are defined below and they are used in the discussions for explaining different concepts.

Angle between two teeth $\left(\theta_{\text {abtt }}\right)$ is given by Eq. 1 .

$\theta_{a b t t}=\frac{360}{n_{f m}}$

Tooth working angle $\left(\theta_{\text {twa }}\right)$ and flute working angle $\left(\theta_{\text {fwa }}\right)$ are defined by Eqs. 2 and 3, respectively.

$\theta_{t w a}=\arccos \left[1-2 \frac{r_{d o c}}{D_{m}}\right]$

$\theta_{f w a}=\frac{2 a_{d o c}}{D_{m} \times \tan \left(90^{\circ}-\lambda_{s m}\right)}$

Number of working teeth $\left(\mathrm{N}_{\mathrm{wt}}\right)$ is the ratio given in Eq. 4 .

$N_{w t}=\frac{\theta_{t w a}}{\theta_{a b t t}}+\frac{\theta_{f w a}}{\theta_{a b t t}}$

This criterion is quite useful to compare various thread milling cutters which do not have the same number of flutes $\left(\mathrm{n}_{\mathrm{fm}}\right)$. Finally, the resultant cutting force $(\mathrm{RF})$ is computed in Eq. 5, using $\left(\mathrm{F}_{\mathrm{x}}, \mathrm{F}_{\mathrm{y}}\right.$, and $\left.\mathrm{F}_{\mathrm{z}}\right)$ measured forces.

$R F=\sqrt{\left(F_{x}^{2}+F_{y}^{2}+F_{z}^{2}\right)}$

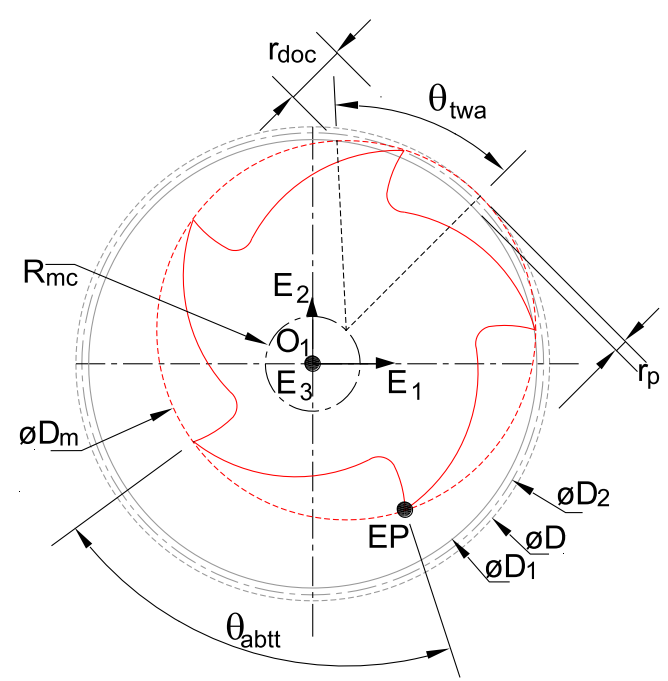

(a)

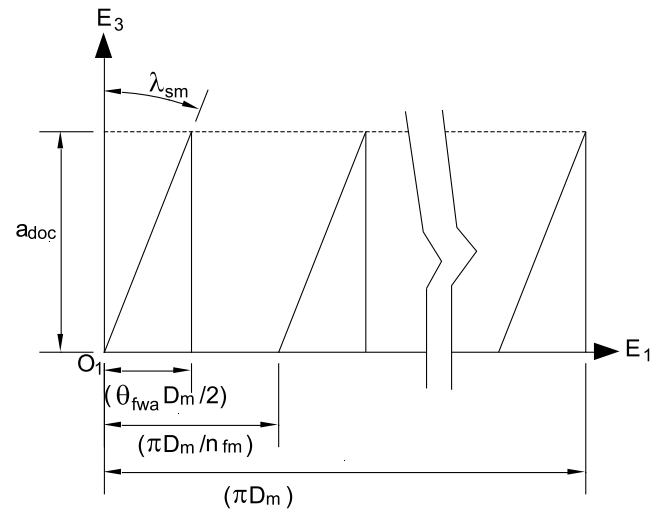

(b)

Fig. 2 Milling cutter $\left(D_{\mathrm{m}}=16 \mathrm{~mm}\right)$ and thread (M20 $\left.\times 1\right)$ : a Full machining configuration; $\mathbf{b}$ developed milling cutter 


\section{Experimental exploration}

The experimental study was undertaken in order to investigate the effect of cutting tool geometry on the cutting forces during thread milling. The experiments were planned taking into consideration the conditions mentioned in Table 1 (geometric mill properties) and Table 2 (cutting conditions). Three mills having different values of flute angle $\left(\lambda_{\mathrm{sm}}\right)$ and orthogonal rake angle on front cutting edge $\left(\gamma_{\mathrm{om}}\right)$ were tested for machining of two different thread dimensions (M20×1, M32×1).

During internal milling operation, the feed of a given point depends on its radial position. Feed $\mathrm{f}_{\mathrm{t}}$ is defined and programmed at the mill center. For comparing the milling of different thread dimension, an identical feed $\mathrm{f}_{\mathrm{tEP}}$ is applied to an external point (EP) on the mill (cf. Fig. 2a). The axial component of feed is not considered because of its inconsiderable influence over this feed determination. As a consequence, feed at mill center is obtained from feed at external point with Eq. 6. Because it is linked to uncut chip thickness, so in order to keep same uncut chip thickness with changing thread diameter.

$f_{t}=f_{t E P} \frac{2 R_{m c}}{D_{m}}$

The machine used for the experiments was a three-axis vertical machining center (Deckel Maho DMC 65V). Aluminum alloy $(\mathrm{AlCu} 4 \mathrm{Mg})$ was opted for study as it exhibits good machinability characteristics. Solid carbide TiCN-coated thread mills were used for the study. Cutting forces were measured with 9123 Kistler rotating dynamometer and data was processed using DASYLab acquisition software.

The dynamometer measures force in tool referential. In thread milling, the orientation of work material relatively to the tool is changing all along the tool path. Then, it affects the force components both in tool referential and in workpiece referential. Furthermore, force criteria $\left(\mathrm{RF}_{\mathrm{ptp}}, \mathrm{RF}_{\mathrm{rms}}\right)$ have to be chosen for comparing the effect of tool geometries or penetration strategies. The analysis of force components was done, but the easiest method is to analyze the resultant force which gives the same conclusion about the input parameter effects. An alternative could be to consider another force referential, perpendicular to the work material and the tool position, as has been reported earlier [11].

Table 1 Geometric mill properties

\begin{tabular}{llllll}
\hline Milling cutter & $\mathrm{D}_{\mathrm{m}}(\mathrm{mm})$ & $\mathrm{P}(\mathrm{mm})$ & $\mathrm{n}_{\mathrm{fm}}$ & $\lambda_{\mathrm{sm}}\left({ }^{\circ}\right)$ & $\gamma_{\mathrm{om}}\left({ }^{\circ}\right)$ \\
\hline T1 & 16 & 1 & 5 & 10 & 9 \\
$\mathrm{~T} 2$ & & & 6 & 20 & 9 \\
T3 & & & 4 & 27 & 3 \\
\hline
\end{tabular}

Table 2 Cutting conditions

\begin{tabular}{ll}
\hline Thread dimensions & M20 $\times 1, \mathrm{M} 32 \times 1$ \\
\hline Milling mode & Down milling \\
Cooling condition & Flood coolant \\
Cutting speed $\left(\mathrm{V}_{\mathrm{c}}\right)$ & $100 \mathrm{~m} / \mathrm{min}$ \\
Feed per tooth $\left(\mathrm{f}_{\mathrm{t}}\right)$ & $\mathrm{f}_{\mathrm{tEP}}=0.1 \mathrm{~mm} / \mathrm{tooth} / \mathrm{rev}$. for M20 $\times 1$ \\
& \& $\mathrm{M} 32 \times 1$ thread and for FM and PS \\
& $\mathrm{M} 20 \times 1 ; \mathrm{f}_{\mathrm{t}}=0.02 \mathrm{~mm} /$ tooth $/ \mathrm{rev}$. during FM \\
& $\mathrm{M} 32 \times 1 ; \mathrm{f}_{\mathrm{t}}=0.05 \mathrm{~mm} /$ tooth $/ \mathrm{rev}$. during FM \\
& $20 \mathrm{~mm}$ \\
\hline
\end{tabular}

The experimental data obtained after the experiments is tabulated in Table 3.

\section{Results and discussions}

For lucidity, this section is divided into subsections namely geometrical analysis, cutting forces analysis during full

Table 3 Experimental data for full machining and penetration

\begin{tabular}{|c|c|c|c|c|c|c|c|}
\hline SN. & $\begin{array}{l}\mathrm{D} \\
(\mathrm{mm})\end{array}$ & Mill & PS & $\mathrm{N}_{\mathrm{wt}}$ & $\begin{array}{l}\mathrm{RF}_{\mathrm{ptp}} \\
(\mathrm{N})\end{array}$ & $\begin{array}{l}\mathrm{RF}_{\text {rms }} \\
(\mathrm{N})\end{array}$ & $\begin{array}{l}\mathrm{RF}_{\mathrm{rms}} / \mathrm{N}_{\mathrm{wt}} \\
\text { (N) }\end{array}$ \\
\hline 1 & 20 & $\mathrm{~T} 1$ & $\mathrm{FM}$ & 1.02 & 423 & 196 & 192 \\
\hline 2 & 20 & $\mathrm{~T} 1$ & SP & $1.68^{\mathrm{a}}$ & 653 & 322 & 192 \\
\hline 3 & 20 & $\mathrm{~T} 1$ & HRP & $1.02^{\mathrm{a}}$ & 490 & 213 & 209 \\
\hline 4 & 20 & $\mathrm{~T} 1$ & QRP & $1.02^{\mathrm{a}}$ & 451 & 207 & 203 \\
\hline 5 & 20 & $\mathrm{~T} 2$ & $\mathrm{FM}$ & 1.67 & 193 & 189 & 113 \\
\hline 6 & 20 & $\mathrm{~T} 2$ & SP & $2.46^{\mathrm{a}}$ & 604 & 350 & 142 \\
\hline 7 & 20 & $\mathrm{~T} 2$ & HRP & $1.67^{\mathrm{a}}$ & 361 & 213 & 128 \\
\hline 8 & 20 & $\mathrm{~T} 2$ & QRP & $1.67^{\mathrm{a}}$ & 354 & 204 & 122 \\
\hline 9 & 20 & $\mathrm{~T} 3$ & $\mathrm{FM}$ & 1.34 & 204 & 178 & 133 \\
\hline 10 & 20 & T3 & SP & $1.87^{\mathrm{a}}$ & 613 & 310 & 165 \\
\hline 11 & 20 & T3 & HRP & $1.34^{\mathrm{a}}$ & 321 & 197 & 147 \\
\hline 12 & 20 & $\mathrm{~T} 3$ & QRP & $1.34^{\mathrm{a}}$ & 301 & 188 & 140 \\
\hline 13 & 32 & $\mathrm{~T} 1$ & FM & 0.77 & 461 & 187 & 183 \\
\hline 14 & 32 & $\mathrm{~T} 1$ & SP & $1.18^{\mathrm{a}}$ & 709 & 354 & 300 \\
\hline 15 & 32 & $\mathrm{~T} 1$ & HRP & $0.77^{\mathrm{a}}$ & 477 & 191 & 248 \\
\hline 16 & 32 & $\mathrm{~T} 1$ & QRP & $0.77^{\mathrm{a}}$ & 406 & 146 & 190 \\
\hline 17 & 32 & $\mathrm{~T} 2$ & $\mathrm{FM}$ & 1.37 & 221 & 165 & 99 \\
\hline 18 & 32 & $\mathrm{~T} 2$ & SP & $1.87^{\mathrm{a}}$ & 562 & 354 & 190 \\
\hline 19 & 32 & $\mathrm{~T} 2$ & HRP & $1.37^{\mathrm{a}}$ & 257 & 162 & 118 \\
\hline 20 & 32 & $\mathrm{~T} 2$ & QRP & $1.37^{\mathrm{a}}$ & 214 & 119 & 87 \\
\hline 21 & 32 & $\mathrm{~T} 3$ & $\mathrm{FM}$ & 1.14 & 265 & 159 & 119 \\
\hline 22 & 32 & $\mathrm{~T} 3$ & SP & $1.87^{\mathrm{a}}$ & 717 & 359 & 193 \\
\hline 23 & 32 & $\mathrm{~T} 3$ & HRP & $1.14^{\mathrm{a}}$ & 334 & 171 & 150 \\
\hline 24 & 32 & T3 & QRP & $1.14^{\mathrm{a}}$ & 238 & 125 & 110 \\
\hline
\end{tabular}

${ }^{\text {a }}$ Value at end of PS 
machine, and cutting forces analysis for different penetration strategies.

\subsection{Geometrical approach and cutting force analysis}

A geometrical model of cutting edge of rake face was developed and computations were carried out on Mathematica [4, 12]. It allows computations of normal rake angle $\left(\gamma_{n}\right)$ along the cutting edge, for a given value of mill flute angle $\left(\lambda_{\mathrm{sm}}\right)$ and orthogonal rake angle on front cutting edge $\left(\gamma_{\mathrm{om}}\right)$. The various angles used in the study are taken with reference to ISO 3002 1:1982 standard [13].

The computed variations of normal rake angle $\left(\gamma_{n}\right)$ as a function of the cutting edge altitude $\left(\mathrm{z}_{\mathrm{ce}}\right)$ for different tools are shown in Fig. 3. It can be seen here that the normal rake angle $\left(\gamma_{n}\right)$ varies from $+13^{\circ}$ to $-3^{\circ}$ on the upper cutting edge (uce) and lower cutting edge (lce), respectively, for T1 milling cutter. Similarly, for T2 milling cutter, it varies from $+21^{\circ}$ to $-12^{\circ}$ and for T3 milling cutter, this variation is between $+24^{\circ}$ and $-20^{\circ}$. The increase of mill flute angle induces negative normal rake angle on the upper cutting edge (uce) of the milling cutter, as it can be seen by the rise in values from $\mathrm{T} 1$ to T3 milling cutters. As a consequence, cutting forces on upper cutting edge (uce) are higher with the mill having negative rake angle. T2 milling cutter is a compromised tool according to normal rake angle $\left(\gamma_{\mathrm{n}}\right)$.

Figure $4 \mathrm{a}$ indicates measured cutting forces for different penetration strategies. Figure $4 \mathrm{~b}$ indicates milled distance $\left(\mathrm{m}_{\mathrm{d}}\right)$. From Fig. $4 \mathrm{a}$, it can be seen that the resultant force values rise sharply for straight penetration (SP), followed by HRP and QRP, respectively. In the case of SP, the cutting force values overshoot the values produced during full machining as indicted by the spike in Fig. 4a. This overshoot is less in the case of HRP as compared to SP, whereas there is no overshoot seen in the case of QRP. Thus, it can be deduced that QRP provides smooth engagement as compared to HRP and SP. The results shown in Fig. 4a have been produced by T2 milling cutter for $\mathrm{M} 32 \times 1$ threads; all the three penetration strategies have been performed at the same cutting conditions.

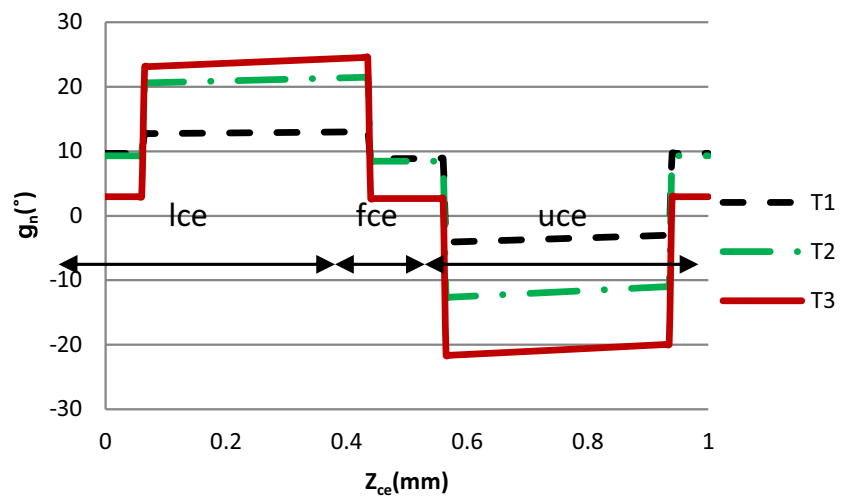

Fig. 3 Normal rake angle for different milling cutters

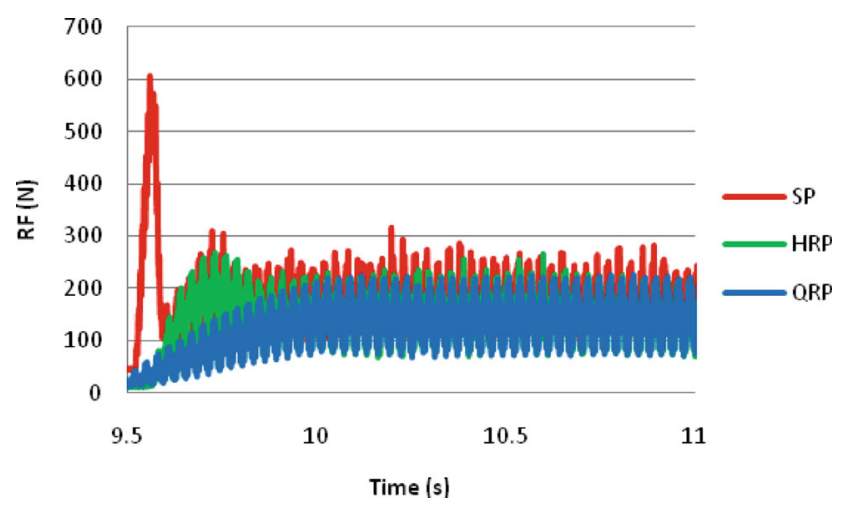

Thread M32x1; Milling cutter T2

(a)

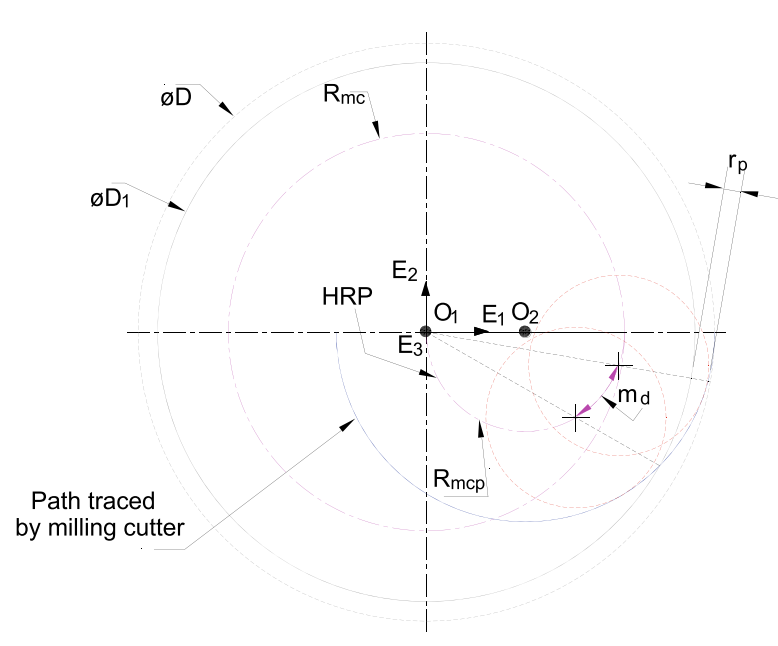

(b)

Fig. 4 a Measured cutting forces for different penetration strategies and full machining; b milled distance $\left(\mathrm{m}_{\mathrm{d}}\right)$

The computed radial penetration $\left(\mathrm{r}_{\mathrm{p}}\right)$, tooth working angle $\left(\theta_{\mathrm{twa}}\right)$, and number of working teeth $\left(\mathrm{N}_{\mathrm{wt}}\right)$ are plotted as a function of milled distance $\left(\mathrm{m}_{\mathrm{d}}\right)$ in the Fig. $5 \mathrm{a}-\mathrm{c}$, respectively. The number of working teeth $\left(\mathrm{N}_{\mathrm{wt}}\right)$ ratio takes into account the different number of tooth $\left(\mathrm{n}_{\mathrm{fm}}\right)$ and mill flute angle $\left(\lambda_{\mathrm{sm}}\right)$ on different milling cutters. Figure $5 \mathrm{a}$ shows that the radial penetration $\left(r_{p}\right)$ reaches the maximum value for SP rapidly, slowly for HRP, and very slowly for QRP. This implies that there is smooth engagement of the milling cutter with the workpiece for QRP. Towards the end of penetration, the radial penetration $\left(r_{p}\right)$ value is the same for all the penetration strategies. Tooth working angle $\left(\theta_{\text {twa }}\right)$ reaches the maximum value rapidly for SP, slowly for HRP, and very slowly for QRP as indicated in Fig. 5b. The variation in the number of working teeth $\left(\mathrm{N}_{\mathrm{wt}}\right)$ along milled distance $\left(\mathrm{m}_{\mathrm{d}}\right)$, shown in Fig. $5 \mathrm{c}$, is linked to the rise of tooth working angle $\left(\theta_{\mathrm{twa}}\right)$. The number of 
Fig. 5 Analysis of penetration strategies (Mill T1): a variation of radial penetration $\left(r_{p}\right)$, b tooth working angle $\left(\theta_{\text {twa }}\right)$, and $\mathbf{c}$ number of working teeth $\left(\mathrm{N}_{\mathrm{wt}}\right)$

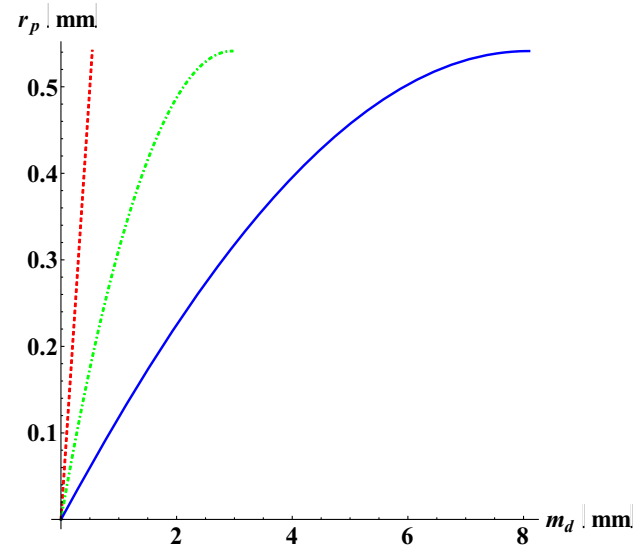

(a)

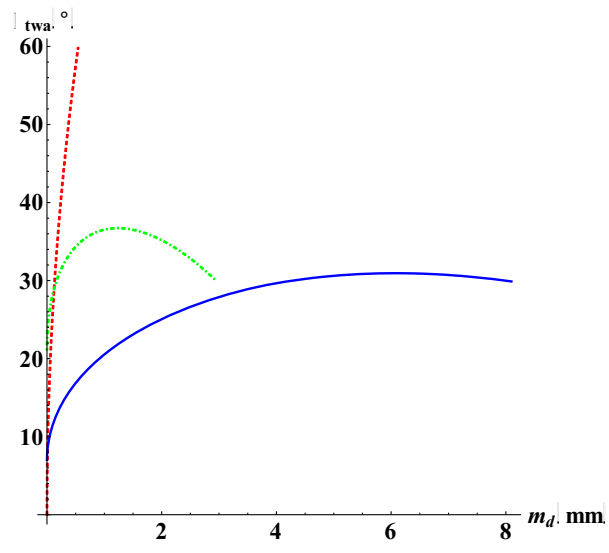

(b)

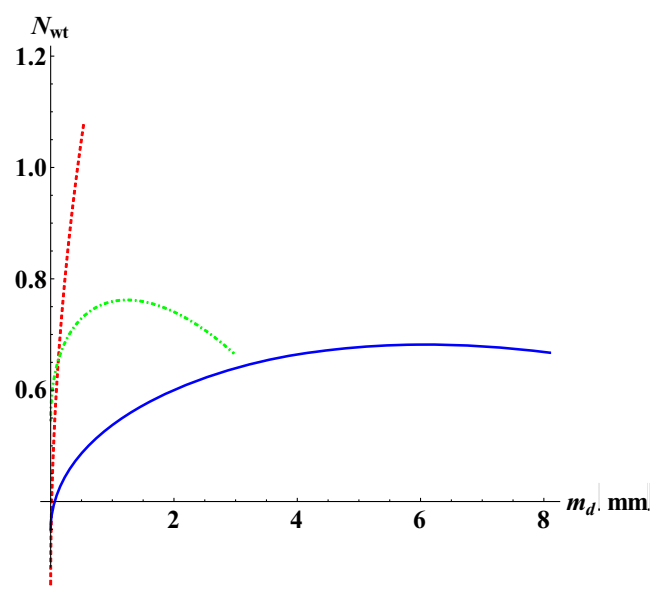

(c)

SP

HRP
QRP

Thread M32x1

working teeth $\left(\mathrm{N}_{\mathrm{wt}}\right)$ is almost double towards the end of cut for SP, whereas it is the same for HRP and QRP. From this discussion, it can be deduced that QRP gives smooth engagement and hence leads to less cutting forces.

\subsection{Cutting forces during full machining}

Figure 6a shows resultant cutting forces, $\mathrm{RF}_{\mathrm{ptp}}, \mathrm{RF}_{\mathrm{rms}}$, and $\mathrm{RF}_{\mathrm{rms}} / \mathrm{N}_{\mathrm{w}}$, during full machining $(\mathrm{FM})$ of $\mathrm{M} 32 \times 1$ and $\mathrm{M} 20 \times$ 1 threads. Figure $6 \mathrm{~b}$ represents the number of working teeth $\left(\mathrm{N}_{\mathrm{wt}}\right)$ for different milling cutters.

It can be seen in Fig. $6 a$ that $\mathrm{RF}_{\mathrm{ptp}}$ is maximum for $\mathrm{T} 1$ milling cutter, then it reduces for T2 milling cutter, and then it again increases for T3 milling cutter. Lower number of working teeth means there is an important chip load variation, which induces higher cutting force variations.
$\mathrm{RF}_{\mathrm{rms}}$ is maximum for $\mathrm{T} 1$ milling cutter and goes on reducing for $\mathrm{T} 2$ and $\mathrm{T} 3$ mills subsequently. $\mathrm{RF}_{\mathrm{rms}}$ is not a good indicator of cutting tool geometry effect because the number of flutes $\left(\mathrm{n}_{\mathrm{fm}}\right)$ and mill flute angles $\left(\lambda_{\mathrm{sm}}\right)$ are different on each milling cutter. So, more significant results are given by $\mathrm{RF}_{\mathrm{rms}} / \mathrm{N}_{\mathrm{wt}}$ ratio. This ratio takes into account both these factors and here it clearly indicates that $\mathrm{T} 2$ milling cutter geometry provides minimum cutting forces for both threads dimensions, i.e., $\mathrm{M} 20 \times 1$ and $\mathrm{M} 32 \times 1$. Figure $6 \mathrm{~b}$ shows that the number of working teeth $\left(\mathrm{N}_{\mathrm{wt}}\right)$, for $\mathrm{T} 2$ milling cutter, is maximum, so the resultant cutting force is minimum. It induces lower cutting forces, less cutting force variations, and thus fewer vibrations.

The use of cylindrical milling cutters with a positive flute angle enables its normal rake angle $\left(\gamma_{n}\right)$ to be increased and hence cutting forces to be shared during one mill revolution. 
Fig. 6 a $R F_{\text {rms }}, R F_{p t p}$, and $\mathrm{RF}_{\mathrm{rms}} / \mathrm{N}_{\mathrm{wt}}$ for different milling cutters; $b \mathrm{~N}_{\mathrm{wt}}$

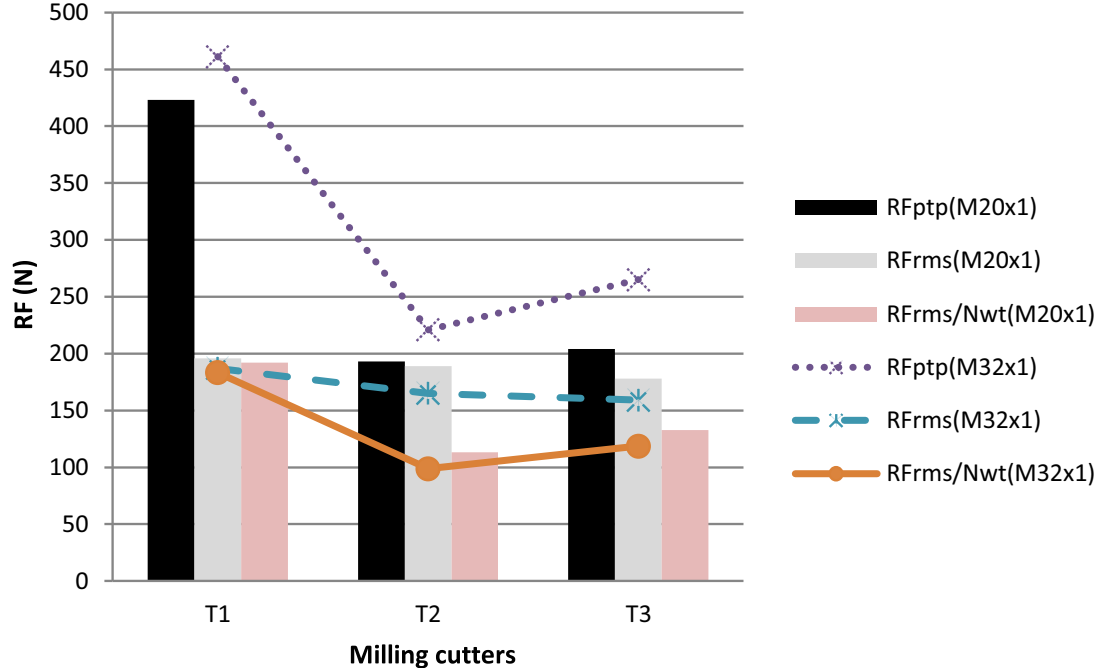

a

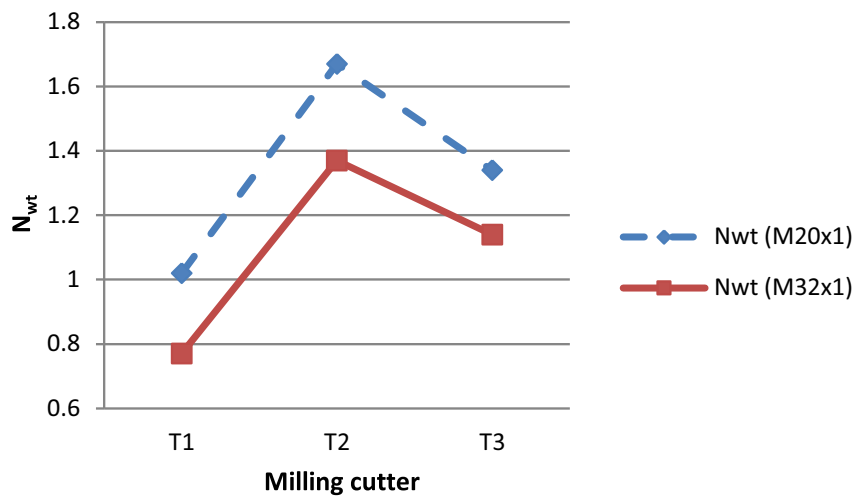

b
Additionally, increasing the radial depth of cut allows a higher number of teeth to be engaged and reduces cutting force variations. But in thread milling, such freedom of settings is not possible. The radial depth of cut $\left(\mathrm{r}_{\mathrm{doc}}\right)$ cannot be changed because the radial penetration $\left(r_{p}\right)$ is determined by the thread pitch. As a consequence, a method for reducing cutting force variations would be to use a thread milling cutter with a high flute angle. Nevertheless, a thread milling cutter designed with
Fig. 7 Resultant forces for different penetration strategies and different milling cutters

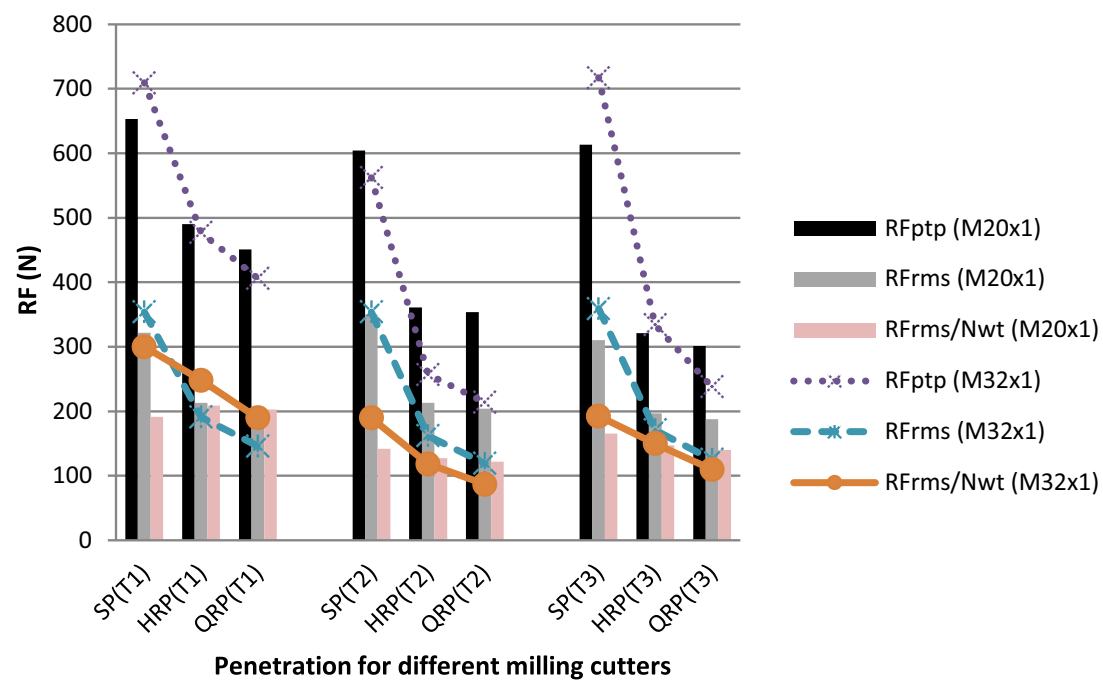


Fig. 8 Computed $\mathrm{N}_{\mathrm{wt}}$ versus $\mathrm{m}_{\mathrm{d}}$ during QRP for different thread dimensions

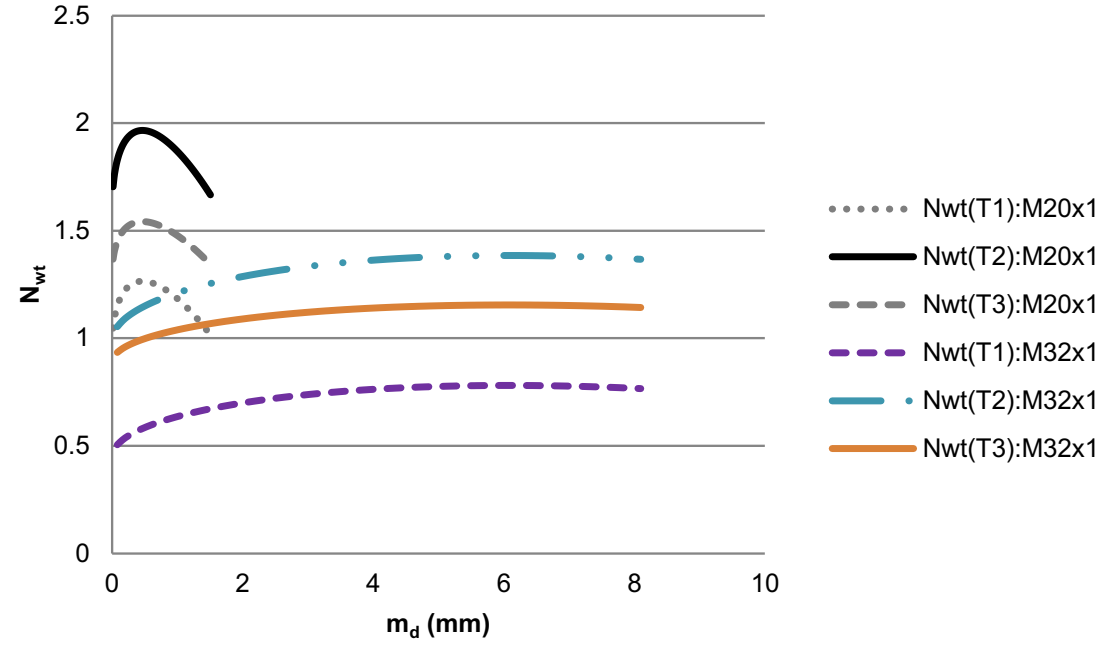

high flute angle introduces a negative rake angle on the upper cutting edge, which leads to higher cutting forces. Therefore, a compromise is necessary in the determination of the flute angle. Hence, in the current study, the tool which gives minimum values of cutting forces, considering the $\mathrm{RF}_{\mathrm{rms}} / \mathrm{N}_{\mathrm{wt}}$ ratio, is $\mathrm{T} 2$ milling cutter.

\subsection{Cutting forces during PS}

Referring to Fig. 7, it can be seen that straight penetration (SP) leads to more resultant cutting force $\left(\mathrm{RF}_{\mathrm{rms}}, \mathrm{RF}_{\mathrm{ptp}}\right.$, and $\mathrm{RF}_{\mathrm{rms}} /$ $\mathrm{N}_{\mathrm{wt}}$ ) values for each milling cutter as compared to HRP and $\mathrm{QRP}$. Further resultant cutting forces $\left(\mathrm{RF}_{\mathrm{rms}}, \mathrm{RF}_{\mathrm{ptp}}\right.$, and $\left.\mathrm{RF}_{\mathrm{rms}} / \mathrm{N}_{\mathrm{wt}}\right)$ values are reduced from straight penetration to HRP for each mill flute angle. There is not much difference between HRP and QRP for M20 $\times 1$ thread since it is a special case where $R_{\mathrm{mc}}=2 \mathrm{P}$ [3]. These penetration strategies are identical because of mill and thread dimension values. But, there is considerable difference between HRP and QRP during machining M $32 \times 1$ thread. The resultant force values are reducing from HRP to QRP. T3 milling cutter behaves best for $\mathrm{RF}_{\mathrm{rms}}$ and $\mathrm{RF}_{\mathrm{ptp}}$ for penetration strategy. This means that these values are less as compared to T1 and T2 milling cutters. From this data, it appears that T3 milling cutter would be the best tool but there are different numbers of tooth and mill flute angles on the tools. So the ratio $\mathrm{RF}_{\mathrm{rms}} / \mathrm{N}_{\mathrm{wt}}$ that was proposed earlier is used here for comparison of tools. Based on this ratio, cutting geometry of $\mathrm{T} 2$ milling cutter is best for penetration as well.

Figure 8 indicates computed variation in the number of working teeth $\left(\mathrm{N}_{\mathrm{wt}}\right)$ versus milled distance for different tools during penetration for QRP. The tool which has the higher number of working teeth is considered the best tool for reducing cutting force variations. For both the cases studied, i.e., $\mathrm{M} 32 \times 1$ and M20 $\times 1$ threads, milling cutter T2 is the best one.
After milling cutter penetration, $\mathrm{N}_{\mathrm{wt}}$ remains constant during full machining.

\section{Conclusions}

The complex process of thread milling was studied and the outcome of this study could lead to ways of improving cutting tool geometry for better reliability of the cutting tool and hence better accuracy. Furthermore, the right penetration strategy was also highlighted. The specific outcome of the investigation of cutting tool geometry effect on cutting forces during thread milling is given below:

- Straight penetration leads to more resultant cutting forces as compared to half revolution penetration and quarter revolution penetration strategies for all the three milling cutters because flute working angle $\left(\theta_{\text {twa }}\right)$ becomes double at the end of penetration strategy.

- The cutting forces are minimum for quarter revolution penetration because of progressive increase of radial penetration $\left(\mathrm{r}_{\mathrm{p}}\right)$ and the number of working teeth $\left(\mathrm{N}_{\mathrm{wt}}\right)$.

- The proposed ratio of resultant force root mean square and the number of working teeth $\left(\mathrm{RF}_{\mathrm{rms}} / \mathrm{N}_{\mathrm{wt}}\right)$ is the best indicator for comparing milling cutters as it takes into account different number of flutes and mill flute angle for different milling cutters. Among the studied milling cutters and based upon the proposed ratio, T2 milling cutter offers best cutting geometry as it produces minimum cutting forces.

- The peak to peak variations of the resultant cutting force is linked to the number or working teeth, and according to this criterion T2 mill appears to be the best among the studied tools. 
The mill flute angle influences cutting force variation due to its effect on the number of working tooth. It also influences cutting force magnitude due to its effect on the normal rake angle. Thus, there has to be an optimized solution for mill flute angle $\left(\lambda_{\mathrm{sm}}\right)$ and orthogonal rake angle $\left(\gamma_{\mathrm{om}}\right)$, which can be further explored.

Acknowledgments The authors express their deepest gratitude towards Burgundy Council, France for providing financial support to carry out this research work in the form of a fellowship. The authors also acknowledge and express their sincere thanks towards M/s Walter Prototyp, Germany for providing cutting tools for the study.

\section{References}

1. Halas D (1996) Tapping versus thread milling. Tool Prod 62:99-102

2. Koelsch JR (2005) Thread milling takes on tapping. Manuf Eng 115: $77-83$

3. Fromentin G, Sharma VS, Poulachon G, Paire Y, Brendlen R (2011) Effect of thread milling penetration strategies on the dimensional accuracy. J Manuf Sci Eng 133:041014-1-041014-13
4. Fromentin G, Poulachon G (2010) Geometrical analysis of thread milling-part 1: evaluation of tool angles. Int J Adv Manuf Technol 49(1-4):73-80

5. Trent EM, Wright PK (2000) Metal cutting. ButterworthHeinemann, Boston, pp 57-58

6. Wen-Hsiang L (2000) Modeling of cutting forces in end milling operations. Tam J Sci Eng 3(1):15-22

7. Wan M, Zhang W (2009) Systematic study on cutting force modelling methods for peripheral milling. Int J Mach Tools Manuf 49:424 432

8. Araujo AC, Silveira JL, Jun MBG, Kapoor SG, DeVor R (2006) A model for thread milling cutting forces. Int $J$ Mach Tools Manuf 46(15):2057-2065

9. Araujo AC, Silveira JL, Kapoor S (2004) Force prediction in thread milling. J Braz Soc Mech Manuf Sci Eng 26(1):82-88

10. Lee SW, Kasten A, Nestler A (2013) Analytic mechanistic cutting force model for thread milling operations. Procedia CIRP 8: $546-551$

11. Araujo AC, Fromentin G, Poulachon G (2013) Analytical and experimental investigations on thread milling forces in titanium alloy. Int $\mathrm{J}$ Mach Tools Manuf 67:28-34

12. Fromentin G, Poulachon G (2010) Modeling of interferences during thread milling operation. Int J Adv Manuf Technol 49(1-4): $41-51$

13. ISO 3002-1:1982 standard, ISO Basic quantities in cutting and grinding-Part 1: Geometry of active part of the cutting tool. 